\title{
Demonstration of drug-resistant bacteria among commonly available flowers within Dhaka Metropolis and assessment of their anti-bacterial properties
}

\author{
Sarah Afrin, Priyanka Basak and Tasmina Rahman* \\ Department of Microbiology, Stamford University Bangladesh, 51 Siddeswari Road, Dhaka 1217, \\ Bangladesh
}

Received 2 February 2015/Accepted 05April 2015

\begin{abstract}
Present study attempted to emphasize on the drug-resistance attribute of the previously isolated microorganisms within the commonly available flowers including Hibiscus rosa-sinensis, Ixora coccinea, Ipomoea digitata, Allamanda cathartica, Nymphaea nouchali, Vinca rosea, Rosa kordesii, Gladiolus hybrid, Acmella oleracea, Nyctanthes arbor-tristis and Pseudomussaenda flava, randomly collected from different areas in Dhaka city, Bangladesh. Conventional agar well diffusion method was applied to examine the antibiogram of the isolates (Escherichia coli, Klebsiella spp., Pseudomonas spp., and Staphylococcus spp.) against different drugs. Subsequently the anti-bacterial traits of 6 flowers such as Rosa kordesii, Gladiolus hybrid, Acmella oleracea, Nymphaea nouchali (Water lily), Hibiscus rosa- sinensis (Jaba), Ixora coccinea (Rangan) were demonstrated through broth micro-dilution methods. Pseudomonas spp. showed sensitivity against almost $42 \%$ tested drugs. Conversely, Staphylococcus spp. (83\%) and Klebsiella spp. (75\%) revealed resistance against highest number of drugs. Among all the pathogens, $E$ coli showed the highest sensitivity (50\%) against all the tested antibiotics. All the isolated bacteria were found to be multi-drug resistant against commonly used antibiotics. Finally six (6) samples unveiled anti-bacterial features against 8 laboratory strains with their MIC concentrations up to $0.2 \mathrm{mg} / \mathrm{mL}$.
\end{abstract}

Key words: Flowers; Microorganisms; Drug-resistance; Anti-bacterial properties

Currently a remarkable number of antibiotic have become non functional or outdated or primitive due to the rapid provenance of resistant or even the multiresistant strains and their use also have been reported to be related with several adverse side effects (such as hypersensitivity) (1-3). Leading the herbal medication could be a choice to treat diseases caused by multi-drug resistant bacteria (4-7). Now a day a significant fraction $(\sim 10 \%)$ of flowering plants are being used to prepare a number of herbal medicines for disease medication since they have been reported to possess the antioxidant activity with wound-healing effects $(5,8-10)$. Consequently the world wide use of flowers to treat diseases is not new with few or no side effects during medication (11-15).

However, apart the effectiveness of flowers of having the anti-bacterial activity, a diverse number of bacteria and fungi has been reported to populate the floral nectar 16. Knowledge on the microorganisms prevailing within flowers could reinforce the hygiene consciousness and to diminish the infections acquired from environment $(4,17)$. Along these lines, present study aimed to identify the drug-resistance traits of the pathogenic isolates as well as the anti-bacterial attributes of the samples.

*Corresponding Author: Mailing address. Tasmina Rahman, Department of Microbiology, Stamford University Bangladesh, 51 Siddeswari Road, Dhaka 1217, Bangladesh, Bangladesh; E-mail: tasmina_mb@yahoo.com.

\section{MATERIALS AND METHODS}

Study area, sampling and sample processing. As described earlier, samples of 11 categories of flowers including Hibiscus rosa-sinensis (Jaba), Ixora coccinea (Rangan), Ipomoea digitata (Giant potato), Allamanda cathartica (Allamanda), Nymphaea nouchali (Water Lily), Vinca rosea (Nayantara), Rosa kordesii, Gladiolus hybrid, Acmella oleracea (Toothache plant), Nyctanthes arbor-tristis (Shiuli) and Pseudomussaenda flava were randomly collected during August 2013October 2013 following standard protocol (18). Microorganisms were isolated and identified as published by Sharmin et al. (4).

Antibiotic susceptibility test for detection of resistant bacteria. In the current study, the pathogenic isolates were examined for their antibiotic susceptibility traits by disc diffusion assay on Mueller-Hinton agar (Difco, Detroit, MI) against commonly used antibiotics following the standard protocol $(19,20)$. Antibiotics used in the study included erythromycin (ERY, $15 \mu \mathrm{g}$ ), amoxicillin (AMO, $30 \mu \mathrm{g}$ ), ceftriaxone (CEF, $30 \mu \mathrm{g}$ ), ciprofloxacin (CIP, $5 \mu \mathrm{g}$ ), streptomycin (SET, $10 \mu \mathrm{g}$ ), ampicillin (AMP, $10 \mu \mathrm{g}$ ), tetracycline (TE, $30 \mu \mathrm{g}$ ), chloramphenicol (CHL, $30 \mu \mathrm{g}$ ), cefixime (CFM, $5 \mu \mathrm{g}$ ), gentamycine (GEN, $10 \mu \mathrm{g}$ ), azythromycin (AZI, $15 \mu \mathrm{g}$ ) and cefalexim (CFL, $30 \mu \mathrm{g})$.

Assay of anti-bacterial properties of flower samples through broth microdilution method (assessment of the minimal inhibitory concentration, MIC). According to the Clinical and Laboratory Standards Institute (CLSI) guidelines, the anti-bacterial activity of flower samples was studied through broth micro-dilution method $(5,21,22)$. In order to determine the MIC of the flower samples, $100 \mu \mathrm{L}$ of bacterial inoculam was prepared with final concentration of $10^{5} \mathrm{cfu} / \mathrm{mL}$ and introduced into appropriately labeled sterile tubes containing MH broth. In current study, different volume of samples ware employed $(16 \mu \mathrm{L}, 32 \mu \mathrm{L}, 64 \mu \mathrm{L}, 128 \mu \mathrm{L}$, $256 \mu \mathrm{L}, 512 \mu \mathrm{L}, 1024 \mu \mathrm{L}$ and $2048 \mu \mathrm{L}$ ) into the MH broth to find out the lowest concentration, whch can trim down the maximum number of bacterial cell (5).

\section{RESULTS AND DISCUSSION}

In developing countries like Bangladesh, the possibility of existence of contaminating microorganisms is very high in food and water as well as other environmental means (23-29). Such a situation further tends to the probable 
onset of contagious diseases caused by the pathogenic bacteria most of which have been found to be drugresistant (30-31). Based on these evidences on the existence of drug-resistance features of the food and water contaminating microorganisms together with the demonstration of the antibiotic resistant pathogenic bacteria in various clinical samples, current study further pondered to the microbiological complications raised by flowers which are indeed very affirm part of the environment.

In the study conducted by Sharmin et al. (4), almost all samples have been found to be populated by a huge range of bacterial and fungal flora. No growth of $E$. coli was detected in Hibiscus rosa-sinensis and Vinca rosea. Pseudomonas spp. and Klebsiella spp. were only found in Ixora coccinea and Hibiscus rosa-sinensis. Staphylococcus spp. was the most prevalent among four types of bacteria. Actinomycetes were also present in almost all flower samples except Ipomoea digitata. Growth of $E$. coli was significant in Nymphaea nouchali, Rosa kordesii, Gladiolus hybrid, Acmella oleracea, Nyctanthes arbor-tristis and Pseudomussaenda flava. Pseudomonas spp. was found in Gladiolus hybrid, Acmella oleracea, Pseudomussaenda flava. Staphylococcus spp. was the most prevalent among all types of bacteria. Nymphaea nouchali was found to harbor actinomycetes (4).

In the aspect of the public health significance, an important attention has to be arisen on the drugs resistance trait of pathogens proliferated in flowers, which may create serious problem in course of diseases medication (1, 33). In developing countries, the problem of resistance may arise from the extensive misuse of antibiotics and for the use of antibiotics during fish harvesting and processing which may decrease the effectiveness of drugs eliminating bacterial infections $(1,34,35)$. Therefore, determination of the complete profile of pathogenic load and their antibiotic resistance in flowers is necessary to estimate the associated public health risk.

In our study $E$. coli exhibited sensitivity against almost $50 \%$ tested drugs. Pseudomonas exhibited sensitivity against $42 \%$ among all tested antibiotics (Table 1). However, Staphylococcus spp. and Klebsiella spp. exhibited highest multi-drug resistance against $83 \%$ and $75 \%$ of drugs, respectively. Interestingly ampicillin and cefalexim was found to be ineffective against all four types of isolated microbes. In contrast, streptomycin and tetracycline exhibited zone of inhibition against all the pathogens. Ciprofloxacin (CIP, $5 \mu \mathrm{g}$ ) and ceftriaxone (CEF, $30 \mu \mathrm{g})$ exhibited highest zone of inhibition $(31 \mathrm{~mm}$ and $33 \mathrm{~mm}$ ) (data not shown) against Pseudomonas and E. coli, respectively.

Anti-bacterial activity of flower samples. Previous reports showed the herbs or plants have the potential antibacterial agent which can retard the rapid propagation of microbial population ${ }^{4-6}$. Present study successfully claim that all the tested flower samples unveiled in vitro antibacterial activity against E. coli, Klebsiella spp., Pseudomonas spp., Bacillus spp., Salmonella spp., Listeria spp., Staphylococcus spp., and Vibrio spp. through broth micro-dilution procedure or the MIC assay (Table 2). The MIC value was recorded for all samples within the range of $0.05 \mathrm{mg} / \mathrm{mL}$ (lowest) $-0.2 \mathrm{mg} / \mathrm{mL}$ (highest) (Table 2). The ideal concentrations of the samples were recorded at $0.2 \mathrm{mg} / \mathrm{mL}$ against all the tested bacteria. The MIC was recorded $0.1 \mathrm{mg} / \mathrm{mL}$ against $E$. coli, Salmonella spp., Pseudomonas spp., Staphylococcus spp., and $0.2 \mathrm{mg} / \mathrm{mL}$ recorded against Klebsiella spp., Vibrio spp., Bacillus spp., and Listeria spp. in case of

TABLE 1. Antimicrobial susceptibility patterns of different pathogenic isolates in flower samples

\begin{tabular}{|c|c|c|c|c|c|c|c|c|}
\hline \multirow{2}{*}{$\begin{array}{l}\text { Organisms } \\
\text { Antibiotics }\end{array}$} & \multicolumn{2}{|c|}{$\begin{array}{c}\text { E. coli } \\
(\mathrm{n}=9)\end{array}$} & \multicolumn{2}{|c|}{$\begin{array}{l}\text { Klebsiella spp. } \\
(\mathrm{n}=2)\end{array}$} & \multicolumn{2}{|c|}{$\begin{array}{l}\text { Pseudomonas spp. } \\
(\mathrm{n}=5)\end{array}$} & \multicolumn{2}{|c|}{$\begin{array}{l}\text { Staphylococcus spp. } \\
(\mathrm{n}=11)\end{array}$} \\
\hline & $\mathrm{R}$ & $\mathrm{S}$ & $\mathrm{R}$ & $\mathrm{S}$ & $\mathrm{R}$ & $\mathrm{S}$ & $\mathrm{R}$ & $\mathrm{S}$ \\
\hline AMP $(10 \mu \mathrm{g})$ & $77.77 \%$ & $22.22 \%$ & $100 \%$ & $0 \%$ & $80 \%$ & $20 \%$ & $72 \%$ & $28 \%$ \\
\hline $\mathrm{CIP}(5 \mu \mathrm{g})$ & $33.33 \%$ & $66.66 \%$ & $100 \%$ & $0 \%$ & $20 \%$ & $80 \%$ & $81.81 \%$ & $18.18 \%$ \\
\hline $\mathrm{SET}(10 \mu \mathrm{g})$ & $11.11 \%$ & $88.88 \%$ & $0 \%$ & $100 \%$ & $0 \%$ & $100 \%$ & $9.09 \%$ & $90.90 \%$ \\
\hline CEF $(5 \mu \mathrm{g})$ & $88.88 \%$ & $11.11 \%$ & $100 \%$ & $0 \%$ & $100 \%$ & $0 \%$ & $72.72 \%$ & $27.27 \%$ \\
\hline AMO $(10 \mu \mathrm{g})$ & $100 \%$ & $0 \%$ & $100 \%$ & $100 \%$ & $80 \%$ & $20 \%$ & $54.54 \%$ & $45.45 \%$ \\
\hline $\mathrm{TE}(30 \mu \mathrm{g})$ & $33.33 \%$ & $66.66 \%$ & $0 \%$ & $100 \%$ & $20 \%$ & $80 \%$ & $18.18 \%$ & $81.81 \%$ \\
\hline $\mathrm{CHL}(10 \mu \mathrm{g})$ & $33.33 \%$ & $66.66 \%$ & $100 \%$ & $0 \%$ & $80 \%$ & $20 \%$ & $100 \%$ & $0 \%$ \\
\hline GEN(10 $\mu \mathrm{g})$ & $33.33 \%$ & $66.66 \%$ & $50 \%$ & $50 \%$ & $80 \%$ & $20 \%$ & $100 \%$ & $0 \%$ \\
\hline AZI $(15 \mu \mathrm{g})$ & $88.88 \%$ & $11.11 \%$ & $100 \%$ & $0 \%$ & $20 \%$ & $80 \%$ & $100 \%$ & $0 \%$ \\
\hline CFL(30 $\mu \mathrm{g})$ & $88.88 \%$ & $11.11 \%$ & $100 \%$ & $0 \%$ & $100 \%$ & $0 \%$ & $72.72 \%$ & $27.27 \%$ \\
\hline ERY $(15 \mu \mathrm{g})$ & $88.88 \%$ & $11.11 \%$ & $100 \%$ & $0 \%$ & $20 \%$ & $80 \%$ & $100 \%$ & $0 \%$ \\
\hline CFM $(5 \mu \mathrm{g})$ & $0 \%$ & $100 \%$ & $100 \%$ & $0 \%$ & $80 \%$ & $20 \%$ & $100 \%$ & $0 \%$ \\
\hline
\end{tabular}

$\mathrm{AMP}=$ Ampicillin, $\mathrm{AMO}=$ Amoxicillin, $\mathrm{CIP}=$ Ciprofloxacin, $\mathrm{CEF}=$ Ceftriaxone, NALI= Nalidixic acid, IPM= Imipenem, ERY= Erythromycin, $\mathrm{CHL}=$ Chloramphenicol, TMP/SUL= Trimethoprime-sulfomethoxazole, $\mathrm{GEN}=$ Gentamicin, $\mathrm{PIP}=\mathrm{Piperaciline}$.

Sensitive- S; Registrant- R; not done- ND 
TABLE 2. Minimum Inhibitory Concentration (MIC) of the samples

\begin{tabular}{|c|c|c|c|c|c|c|c|c|}
\hline \multirow[b]{2}{*}{ Sample } & \multicolumn{8}{|c|}{ Organisms } \\
\hline & E. coli & $\begin{array}{l}\text { Klebsiella } \\
\text { spp. }\end{array}$ & $\begin{array}{c}\text { Salmonella } \\
\text { spp. }\end{array}$ & $\begin{array}{l}\text { Vibrio } \\
\text { spp. }\end{array}$ & $\begin{array}{c}\text { Pseudomoas } \\
\text { spp. }\end{array}$ & Bacillus spp. & $\begin{array}{l}\text { Staphylococcus } \\
\text { spp. }\end{array}$ & $\begin{array}{c}\text { Listeria } \\
\text { spp. }\end{array}$ \\
\hline $\begin{array}{c}\text { Rosa } \\
\text { kordesii }\end{array}$ & $0.1 \mathrm{mg} / \mathrm{mL}$ & $0.2 \mathrm{mg} / \mathrm{mL}$ & $0.1 \mathrm{mg} / \mathrm{mL}$ & $0.2 \mathrm{mg} / \mathrm{mL}$ & $0.1 \mathrm{mg} / \mathrm{mL}$ & $0.2 \mathrm{mg} / \mathrm{mL}$ & $0.1 \mathrm{mg} / \mathrm{mL}$ & $0.2 \mathrm{mg} / \mathrm{mL}$ \\
\hline $\begin{array}{l}\text { Gladiolus } \\
\text { hybrid }\end{array}$ & $0.2 \mathrm{mg} / \mathrm{mL}$ & $0.2 \mathrm{mg} / \mathrm{mL}$ & $0.1 \mathrm{mg} / \mathrm{mL}$ & $0.2 \mathrm{mg} / \mathrm{mL}$ & $0.05 \mathrm{mg} / \mathrm{mL}$ & $0.2 \mathrm{mg} / \mathrm{mL}$ & $0.1 \mathrm{mg} / \mathrm{mL}$ & $0.1 \mathrm{mg} / \mathrm{mL}$ \\
\hline $\begin{array}{l}\text { Acmella } \\
\text { oleracea }\end{array}$ & $0.2 \mathrm{mg} / \mathrm{mL}$ & $0.1 \mathrm{mg} / \mathrm{mL}$ & $0.2 \mathrm{mg} / \mathrm{mL}$ & $0.2 \mathrm{mg} / \mathrm{mL}$ & $0.2 \mathrm{mg} / \mathrm{mL}$ & $0.05 \mathrm{mg} / \mathrm{mL}$ & $0.2 \mathrm{mg} / \mathrm{mL}$ & $0.2 \mathrm{mg} / \mathrm{mL}$ \\
\hline $\begin{array}{c}\text { Nymphaea } \\
\text { nouchali } \\
\text { (Water lily) }\end{array}$ & $0.1 \mathrm{mg} / \mathrm{mL}$ & $0.05 \mathrm{mg} / \mathrm{mL}$ & $0.1 \mathrm{mg} / \mathrm{mL}$ & $0.1 \mathrm{mg} / \mathrm{mL}$ & $0.2 \mathrm{mg} / \mathrm{mL}$ & $0.2 \mathrm{mg} / \mathrm{mL}$ & $0.1 \mathrm{mg} / \mathrm{mL}$ & $0.1 \mathrm{mg} / \mathrm{mL}$ \\
\hline $\begin{array}{c}\text { Hibiscus } \\
\text { rosa- } \\
\text { sinensis } \\
\text { (Jaba ) } \\
\text { Ixora }\end{array}$ & $0.2 \mathrm{mg} / \mathrm{mL}$ & $0.2 \mathrm{mg} / \mathrm{mL}$ & $0.2 \mathrm{mg} / \mathrm{mL}$ & $0.2 \mathrm{mg} / \mathrm{mL}$ & $0.1 \mathrm{mg} / \mathrm{mL}$ & $0.1 \mathrm{mg} \mathrm{mL}$ & $0.05 \mathrm{mg} / \mathrm{mL}$ & $0.2 \mathrm{mg} / \mathrm{mL}$ \\
\hline $\begin{array}{l}\text { coccinea } \\
\text { (Rangan ) }\end{array}$ & $0.05 \mathrm{mg} / \mathrm{mL}$ & $0.1 \mathrm{mg} / \mathrm{mL}$ & $0.2 \mathrm{mg} / \mathrm{mL}$ & $0.1 \mathrm{mg} / \mathrm{mL}$ & $0.2 \mathrm{mg} / \mathrm{mL}$ & $0.2 \mathrm{mg} / \mathrm{mL}$ & $0.2 \mathrm{mg} / \mathrm{mL}$ & $0.2 \mathrm{mg} / \mathrm{mL}$ \\
\hline
\end{tabular}

The experiment was conducted three times independently, and the results were found to be reproducible. One representative data has been shown.

$\mathrm{mg} / \mathrm{mL}$ against E. coli, Klebieilla spp., Vibrio spp., and Bacillus spp., while the endurance of Salmonella spp., Staphylococcus spp., and Listeria spp. were found to be inhibited at $0.1 \mathrm{mg} / \mathrm{mL}$ and $0.05 \mathrm{mg} / \mathrm{mL}$. recorded for Pseudomonas spp. The growth of E. coli, Pseudomonas spp., Salmonella spp., Listeria spp., Staphylococcus spp., and Vibrio spp. were found to be stalled at $0.2 \mathrm{mg} / \mathrm{mL}$ even as the MIC was noticed at $0.1 \mathrm{mg} / \mathrm{mL}$ and 0.05 $\mathrm{mg} / \mathrm{mL}$ for Klebsiella spp., and Bacillus spp. respectively in case of Acmella oleracea sample. The MIC was recorded for Nymphaea nouchali at $0.1 \mathrm{mg} / \mathrm{mL}$ against $E$. coli, Salmonella spp., Staphylococcus spp., Vibrio spp., Listeria spp. and $0.2 \mathrm{mg} / \mathrm{mL}$ against Pseudomonas spp. and Bacillus spp. while $0.05 \mathrm{mg} / \mathrm{mL}$ was recorded against Klebseilla spp. For Hibiscus rosa-sinensis, MIC was noticed at $0.2 \mathrm{mg} / \mathrm{mL}$ for E. coli, Klebsiella spp., Salmonella spp., Listeria spp., and Vibrio spp., 0.05 $\mathrm{mg} / \mathrm{mL}$ recorded for Staphylococcus spp. and $0.1 \mathrm{mg} / \mathrm{mL}$ recorded for Pseudomonas spp. and Bacillus spp. For sample Ixora coccinea, MIC was noticed at $0.2 \mathrm{mg} / \mathrm{mL}$ for Pseudomonas spp., Bacillus spp., Salmonella spp., Listeria spp., Staphylococcus spp., $0.05 \mathrm{mg} / \mathrm{mL}$ recorded for E. coli and $0.1 \mathrm{mg} / \mathrm{mL}$ recorded for Klebsiella spp. and Vibrio spp. (Table 2).

\section{CONCLUSION}

Overall, the result of the present study revealed that the extracts of 6 flower samples were found to have potential anti-bacterial activity which can effectively reduce the growth of pathogenic isolates including multi-drug resistant strain. The extraction of pilot ingredients from such flower would largely aid to plot the template for the production of new antibiotics.

\section{ACKNOWLEDGEMENT}

Authors are thankful to the Department of Microbiology, Stamford University Bangladesh for all the technical help.

\section{REFERENCES}

01. Dutta S, Hassan MR, Rahman F, Jilani MFA, Noor R. 2013. Study of antimicrobial susceptibility of clinically significant microorganims isolated from selected areas of Dhaka, Bangladesh. Bangladesh J Med Sci. 12: 3442 .

02. Molton JS, Tambyah PA, Ang BS, Ling ML, Fisher DA. 2013. The global spread of healthcare-associated multidrug-resistant bacteria: a perspective from Asia. Clin Infect Dis. 56:1310-8.

03. Khan SA, Feroz F, Noor R. 2013. Study of extended spectrum $\beta$ lactamase producing bacteria from urinary tract infection in Dhaka city, Bangladesh. Tzu Chi Med J. 25: 39-42.

04. Sharmin M. Banya PD, Paul L. Chowdhury FFK, Afrin S, Acharjee M, et al. 2015. Study of microbial proliferation and the in vitro antibacterial traits of commonly available flowers in Dhaka Metropolis. Asian Pac J Trop Dis. 5 (2): 91-97.

05. Sharmin M, Nur IT, Acharjee M, Munshe SK, Noor R. 2014 Microbiological profiling and the demonstration of in vitro anti-bacterial traits of the major oral herbal medicines used in Dhaka Metropolis. SpringerPlus 3: 739 .

06. Djeussi DE, Noumedem JAK, Seukep JA, Fankam AG, Voukeng IK, Tankeo SB, et al. 2013. Antibacterial activities of selected edible plants extracts against multidrug-resistant Gram-negative bacteria. BMC Complementary and Alternative Medicine. 13: 164

07. Kraft K. 2009. Complementary/Alternative Medicine in the context of prevention of disease and maintenance of health. Prev Med. 49: 88-92.

08. Kucekova Z, Jiri M, Petr H, Otakar R. 2013. Edible flowers antioxidant activity and impact on cell viability. Cent European J Bio. 8: 1023-1031.

09. Gauthaman KK, Saleem MTS, Thanislas PT, Prabhul VV, Krishnamoorthy KK, Devaraj NS, et al. 2006. Cardioprotective effect of the Hibiscus rosasinensis flowers in an oxidative stress model of myocardial ischemic reperfusion injury in rat. BMC Complementary and Alternative Medicine. 6: 32.

10. Yamasaki H, Uefuji H, Sakihama Y. 1996. Stress proteins and myocardial protection. Arch Biochem Biophys. 332: 183-186.

11. World Health Organization. 2013. WHO traditional medicine strategy, 2014-2023. WHO Press, Geneva, Switzerland.

12. Kumari K, Gupta S. 2013. Phytopotential of Catharanthus roseus L.G. Don. Var. "Rosea" And "Alba" against various pathogenic microbes in vitro. Int J Res Pure Appl Microbiol. 3: 77-82. 
13. Rajamanickan K, Sudha SS. 2013. In-vitroantimicrbial activity and invivo toxicity of MoringaoleIferaand Allmanda cathartica against multiple drug resistance clinical pathogens. Int J Pharm Bio Sci. 4: 768-775.

14. Rao ML, Bhumi G, Savithramma N. 2013. Green Synthesis of Silver Nanoparticles by Allamanda cathartica L. Leaf Extract and Evaluation for Antimicrobial Activity. International J Pharm Sci Nanotec. 6 (4): 22602268 .

15. Ruban P, Gajalakshmi K. 2012. In vitro antibacterial activity of Hibiscus rosa-sinensis flower extract against human pathogens. Asian Pac J Trop Biomed. 2: 399-403

16. Canto A, Herrera CM. 2012. Microorganisms behind the pollination scenes: microbial imprint on floral nectar sugar variation in a tropical plant community. Annals of Botany 110: 1173-1183.

17. Kates SG, McGinley KJ, Larson, EL, Leyden JJ. 1991. Indigenous multiresistant bacteria from flowers in hospital and nonhospital environments. Am J Infect Control. 19: 156-61.

18. American Public Health Association. 1998. Standard methods for the examination of water and wastewater. American Public Health Association, Washington, D.C.

19. Bauer AW, Kirby WMM, Sherris JC. 1966. Turk M. Antibiotic susceptibility testing by a standardized single disk method. Am J Clin Pathol. 45: 493-496.

20. Ferraro MJ, Craig WA, Dudley MN. 2001. Performance standards for antimicrobial susceptibility testing, NCCLS, Pennsylvania, USA.

21. Clinical and Laboratory Standards Institute. 2008. Performance standards of antimicrobial disk susceptibility test: Ninth Informational Supplement. NCCLS document

22. Carson CF, Hammer KA, Riley TV. 1995. Broth micro-dilution method for determination of susceptibility of Escherichia coli and Staphylococcus aureus to the essential oil of Malaleuca alterifolia .Tea tree oil. Microbios 82: 181-185.

23. Feroz F, Senjuti JD, Noor R. 2013. Determination of microbial growth and survival in salad vegetables through in vitro challenge test. Int $\mathbf{J}$ Nut Food Sci. 2: 312-319.
24. Fatema N, Acharjee M, Noor R. 2013. Microbiological profiling of imported apples and demonstration of bacterial survival capacity through in vitro challenge test. Am J Microbiol Res. 1: 98-104.

25. Noor R, Acharjee M, Ahmed T, Das KK, Paul L, Munshi SK, et al. 2013. Microbiological analysis of major sea fish collected from local markets in Dhaka city. J Microbiol Biotechnol Food Sci. 2: 2420-2430.

26. Noor R. Uddin MA, Haq MA, Munshi SK, Acharjee M, Rahman MM. 2013. Microbiological study of vendor and packed fruit juices locally available in Dhaka city, Bangladesh. Int Food Res J. 20: 1011-1015.

27. Acharjee M, Fatema K, Jahan F, Siddique SJ, Uddin MA, Noor R. 2013. Prevalence of Vibrio cholerae in different food samples in the city of Dhaka, Bangladesh. Int Food Res J. 20: 1017-1022.

28. Hassan MR, Acharjee M, Das E, Das KK, Ahmed T, Akond MA, et al. 2013. Microbiological study of sea fish samples collected from local markets in Dhaka city. Int Food Res J. 20: 1491-1495.

29. Rahman F, Noor R. 2012. Prevalence of pathogenic bacteria in common salad vegetables of Dhaka Metropolis. Bangladesh J Bot. 41: 159-162.

30. Noor R, Akhter S, Rahman F, Munshi SK, Kamal SMM, Feroz F 2013c. Frequency of extensively drug resistant tuberculosis .XDR-TB. among re-treatment cases in NIDCH, Dhaka, Bangladesh. J Infec Chemo. 19: 243 - 248 .

31. Acharjee M, Jahan F, Rahman F, Noor R. 2013. Bacterial Proliferation in Municipal Water Supplied in Mirpur Locality of Dhaka City, Bangladesh. Clean - Soil, Air, Water. 42 (4): 434-441.

32. Ahmed T, Baidya S, Sharma BC, Malek M, Das KK, Acharjee M, et al. 2013. Identification of drug-resistant bacteria among export quality shrimp samples in Bangladesh. Asian J Microbiol Biotech Env Sc. 15: 31-36.

33. Tenover FC. 2006. Mechanisms of Antimicrobial Resistance in Bacteria Ame J Med. 119: 3-10.

34. Allerberger F, Mittermayer H. 2008. Antimicrobial stewardship. Clin Microbiol Infect. 14: 197-199.

35. Jilani MSA, Murshed M, Sultana L, Hasan Z. 2008. Common clinically important aerobic bacteria and their antibiotic resistance pattern of Dhaka city and its vicinity. Bang Med Col J. 14: 66-71. 